\title{
How the West was Lost: Chief Information Officers and the Battle of Jurisdictional Control
}

\author{
Johan Magnusson \\ University of Gothenburg \\ Kristiania University College \\ Johan.magnusson@gu.se
}

\author{
Erik Högberg \\ University of Gothenburg
}

\author{
Hampus Sjöman \\ University of Gothenburg
}

\begin{abstract}
Recent research has highlighted the potential downfall of the role and profession of Chief Information Officer (CIO). As the top executive responsible for IT in an organization, this role has gone through several shifts since its advent in the 1980's. This study addresses how the role has evolved, and, explores how it may evolve in the years to come. The study utilizes a combination of structured literature review and interviews, and is informed by Abbott's systems of professions perspective. The findings show that after an increase in jurisdictional control prior to the turn of the millennium, the profession has decreased and is continuing to decrease its jurisdictional control. This is in part linked to the imposition of IT Governance frameworks designed to shift risk from the profession of CIOs to neighboring professions. This is discussed in light of calls for future research.
\end{abstract}

Keywords: Chief Information Officer, IT Governance, Profession, Control

\section{Introduction}

Chief Information Officers (CIOs) have long been considered a focal actor in the digital transformation of organizations and enterprises alike. Poised in the nexus of technology and business, they have throughout the years experienced an increase in social stature and hierarchal positioning in organizations, increasingly part of the top management team and board of directors [24; 44]].

Albeit a winding road, the role of the CIO has reportedly emerged from that of a technology-focused corporate savior in the 1980's [16], to a business-savvy member of the higher echelons of management, and, a strategic innovation partner in business in the 2010's [39; 40].

Despite its apparent status, the reports of the demise of the role are increasingly appearing within both research and practice [12;39]. New roles such as that of the Chief Digital Officer (CDO) is promoted as necessary for attaining the full benefits of digitalization, a task that previously was seen as belonging to the CIO [12]. At the same time, we see but few examples of empirical studies that target the profession of CIO.

Research within the field of sociology of work and occupation has devoted significant resources to understanding the evolution of professions and occupations. In Abbott [1], the evolution of professions is studied from the vantage point of how neighboring professions fight for what is referred to as "jurisdictional control", i.e. which decisions are controlled by which professions. In lieu of this, jurisdictional control becomes a vantage point into studying the evolution of the CIO profession. With a majority of IT Governance research applying. the perspective of locus of authority, accountability and control [see e.g. 56], the construct of jurisdictional control is regarded as particularly in tune with previous research and hence relevant.

On the basis of this, the research question guiding this study is:

How has and will the jurisdictional control of the profession of CIOs evolve?

The research question is answered through interpreting data from literature and interviews into three distinct phases (past, present and future), with links to historical battles where the outcome (victory, defeat and retreat) is used as illustrations of the profession's evolution.

This study contributes through an empirically substantiated account of the evolution of the profession of CIO. The particular focus on jurisdictional control offers an avenue to a more nuanced description and exploration of the CIO profession, highlighting not only what has and is happening, but also initiating a discussion on why the profession is evolving along a particular path. 
The paper is organized accordingly. After this brief introduction, we present the precursory findings and analytical framing of the study. This is followed by the results, portraying the evolution of the CIO profession in three stages (past, present and future). Towards the end of the paper, we offer a discussion on the findings and highlight potential avenues for future research.

\section{Previous research and theoretical framing}

\subsection{The role of the CIO}

Previous research has explored the evolution of the CIO from a multitude of different perspectives. When the CIO profession emerged, it was organized under the Chief Financial Officer [31]. A reoccurring theme in research has been how these two professions collaborate and the importance of their relationship, with a distinct focus on IT-investments $[6 ; 14 ; 22 ; 27$; $32 ; 34 ; 35 ; 36 ; 51 ; 52 ; 55 ; 59$ ].

The CIOs reporting structure and involvement in the Top Management Team (TMT) has also been studied in detail [44; 57]. Banker et al. [3] argue that there is a link between performance and reporting structures for the CIO. In organizations with cost leadership as generic strategy, the CIO should report to the CFO, whereas in organizations with differentiation as generic strategy, reporting should be done to the CEO. Throughout history, researchers have suggested that the CIO should report to the CEO and that their partnership is critical to utilize the $\mathrm{CIO}$ as a strategic resource for the organization $[2 ; 13 ; 17 ; 21 ; 26 ; 41$; 45], even though other executives have had a negative attitude towards the $\mathrm{CIO}$, due to mismatching expectations and the difficulty in measuring their value $[3 ; 7 ; 12 ; 25 ; 40 ; 43 ; 49]$.

\subsection{The system of professions and inter- jurisdictional conflicts}

Within the sociology of work and occupations, several studies have strived to offer comprehensive support for understanding the inter- and intra-play of professions. In contrast with the foundational work of Raelin [46] on what constitutes a profession versus an occupation, this study utilizes a non-discriminate definition of profession. In lieu of this, a profession is regarded simply as an occupational group that shares certain common characteristics.

Abbott [1] offers an overarching theory for understanding how professions emerge in what is referred to as a "system of professions". This approach has been highly influential in other types of profession studies such as that of the medical profession [50]. Core to the logic of Abbott's systems theory of professions is the evolution of professions through inter-jurisdictional conflicts. A jurisdictional conflict is when the borders between existing professions become contested, and one profession attempts to increase its dominion at the cost of another profession.

This is clearly illustrated in Samuel et al [50] where the medical profession is under siege by engineers and accountants that increase their scope of control in the hospital setting. Models of diagnosis, inference and treatment from the accounting profession is increasingly used to make traditional medical decisions in what Samuel [50] refers to the "monetization of medicine".

In Magnusson [28], Abbott's theory is used for the first time to understand the emergence of the profession of the CIO. According to these findings, the CIO had in 2010 evolved from a professional man (strong focus on technical know-how and identification with the IT function) to a corporate man (strong focus on financials and identification with the TMT) and further on to a marginal man (torn between the technical and financial at a high personal cost). Unfortunately, there have been no later additions where Abbott's theory has been used to increase our understanding of the evolution of the CIO profession.

Abbott [1] identifies eleven mechanisms for jurisdictional control (see table 1) within the areas of System properties (Connectivity, Dominance, Residuality and Systematization), Cognitive strategies (Reduction, Treatment and Metaphor), Abstraction (Formalism and Content) and Maintenance (Amalgamation and Division). These are used as the theoretical lens for answering the research question in this study.

Table 1. Abbott's System of Professions.

\begin{tabular}{|l|l|}
\hline Mechanism & Description \\
\hline Connectivity & $\begin{array}{l}\text { The degree to which the profession is } \\
\text { connected with its actors (professions, } \\
\text { tasks, jurisdictions). }\end{array}$ \\
\hline Dominance & $\begin{array}{l}\text { Dominance can be either structural } \\
\text { (organizations and institutions) or cultural } \\
\text { (control of dominant ideas) and refers to } \\
\text { how the profession enacts control. }\end{array}$ \\
\hline Residuality & $\begin{array}{l}\text { As a dominant profession becomes more } \\
\text { dominant, their abstract knowledge is } \\
\text { weakened, and they are prone to attacks. }\end{array}$ \\
\hline $\begin{array}{l}\text { Systemization } \\
\text { of professional } \\
\text { knowledge }\end{array}$ & $\begin{array}{l}\text { The degree of systemization of } \\
\text { professional knowledge. A high degree of } \\
\text { systemization lends itself to attacks } \\
\text { through reduction whilst a low degree of } \\
\text { systemization tends to ignore complex } \\
\text { problems. }\end{array}$ \\
\hline Reduction & $\begin{array}{l}\text { The act of redefining another professions } \\
\text { jurisdiction to one that better suits their } \\
\text { own by replacing their diagnosis. }\end{array}$ \\
\hline Treatment & The act of applying one's treatment to a \\
\hline
\end{tabular}




\begin{tabular}{|l|l|}
\hline Metaphor & problem diagnosed by another profession. \\
\hline $\begin{array}{l}\text { Positive } \\
\text { formalism } \\
\text { through metaphors. }\end{array}$ & $\begin{array}{l}\text { Be in control of less jurisdiction in order } \\
\text { to strengthen the abstract knowledge of } \\
\text { each. }\end{array}$ \\
\hline Lack of content & $\begin{array}{l}\text { Be in control of several jurisdictions at } \\
\text { the expense of abstract knowledge of } \\
\text { each jurisdiction. }\end{array}$ \\
\hline Amalgamation & $\begin{array}{l}\text { Merge tasks into one profession, creating } \\
\text { a jurisdiction with all task performed by } \\
\text { said groups. }\end{array}$ \\
\hline Division & $\begin{array}{l}\text { Divide a profession into different } \\
\text { professions based upon tasks. }\end{array}$ \\
\hline
\end{tabular}

\section{Method}

This study involves two sub-studies. First, a structured literature review was conducted in order to explore how the system of professions for the CIO has evolved from the past (1980-2000) to the present (2000-2017). The literature review involved five iterations where the first 23.000 hits in EBSCO was narrowed down to 232 through a trial-and-error approach to additional complementing keywords. After reading the abstracts of said 232 articles, a last selection was done to a total of 57 articles from the 1980-2017. Second, an interview study directed towards 19 CIOs was used in order to explore how the profession will evolve from the present to the future.

The interview study involved an empirical selection of CIOs in 19 large (>250 employees) organizations. The rationale for targeting larger organizations was that organizational complexity was assumed to influence CIO professionalism. Eight of the organizations where from the public sector, whereas eleven were from the private (see Table 2 for overview).

Data was collected through semi-structured interviews that were sound recorded and transcribed verbatim.

Table 2. Overview of respondents.

\begin{tabular}{|l|l|l|l|l|}
\hline $\begin{array}{c}\text { Respon- } \\
\text { dent [\#] }\end{array}$ & Sector & \multicolumn{1}{|c|}{ Industry } & $\begin{array}{c}\text { Age } \\
{[\mathrm{Y}]}\end{array}$ & $\begin{array}{c}\text { Tenure } \\
{[\mathrm{Y}]}\end{array}$ \\
\hline 1 & Public & Agency & $50-59$ & 20 \\
\hline 2 & Public & Healthcare & $40-49$ & 10 \\
\hline 3 & Public & Education & $50-59$ & 15 \\
\hline 4 & Public & Healthcare & $50-59$ & 6 \\
\hline 5 & Public & NPO & $50-59$ & 5 \\
\hline 6 & Public & Education & $60-69$ & 10 \\
\hline 7 & Public & Agency & $50-59$ & 7 \\
\hline 8 & Public & Education & $60-69$ & 10 \\
\hline 9 & Private & Logistics & $60-69$ & 25 \\
\hline 10 & Private & Finance & $40-49$ & 4 \\
\hline 11 & Private & Groceries & $50-59$ & 10 \\
\hline 12 & Private & Logistics & $50-59$ & 4 \\
\hline
\end{tabular}

\begin{tabular}{|l|l|l|l|l|}
\hline 13 & Private & IT services & $50-59$ & 16 \\
\hline 14 & Private & Automotive & $40-49$ & 4 \\
\hline 15 & Private & Finance & $30-39$ & 2 \\
\hline 16 & Private & Cons. Goods & $40-49$ & 6 \\
\hline 17 & Private & Insurance & $40-49$ & 6 \\
\hline 18 & Private & Recycling & $50-59$ & 8 \\
\hline 19 & Private & Event & $40-49$ & 2 \\
\hline
\end{tabular}

The data was analyzed using Abbott's [1] systems of professions perspective in order to derive the system properties, cognitive strategies, abstraction and the maintaining of jurisdictional control of the CIO profession. On the basis of this, we identified common patterns of the system of professions in the three different time-frames. As a last step in the analysis, we linked the patterns to historical battles that we saw as illustrative of the evolution of the CIO profession.

\section{Results: The Battle of Jurisdictional Control}

The results are presented in a dramatized setting with references to three major battles signifying victory (Past: The Bastille), defeat (Present: Waterloo) and retreat (Future: Dunkirk). The rationale for this is to illustrate the dominant evolutionary path within each of the three time-periods.

\subsection{Past: The Bastille}

\author{
"No sire, its not a revolt, it's a \\ revolution." The Duke of \\ Rochefoucauld to Louis XVI after \\ the storming of the Bastille.
}

The CIO burst upon the mainstream scene as a "corporate savior" in the late 1980's [16]. During this period, there was an increased interest in how IT could be used as a means to create sustainable competitive advantage, and the CIO became the modus through which this was to be achieved $[4 ; 30 ; 42 ; 48]$.

As the profession emerged and started to thrive, it survived adversity in the form of high turnover rates $[12 ; 19 ; 38]$, misaligned perspectives on IT and surrealistic expectations [17; 23], and continually increased its standing in the higher cadres of management and the board of directors $[10 ; 11 ; 17$; 44].

Part of this swift success lay in the professions ability to adhere to and utilize new ways of communication, where the $\mathrm{CIO}$ was fast in adapting to a business vernacular in internal communication [12; 23]. Through mastering the language of business, this made it easier for the profession to utilize reduction and treatment attacks to increase their jurisdictional 
control. At the same time, the increased dependence on non-technical language and skills also shifted the role of the CIO towards that of a generalist rather than a specialist [40]. This in turn affected the professions abstract knowledge, which was reduced in conjunction with increased jurisdictional control. To handle the increased jurisdictional control, the profession delegated tasks to subordinates $[15 ; 17 ; 19]$, resulting in a burgeoning division of the profession.

During the past, the CIO became an incumbent profession, with increased dominance and influence in strategic decision making $[13 ; 20 ; 24 ; 41 ; 44 ; 47]$. Even though the profession's residuality started to decrease over time, the CIO was still faced with challenges due to its ambiguity $[7 ; 12 ; 25 ; 37 ; 49 ; 40]$.

\subsection{Present: Waterloo}

\author{
"...for by the rules of war I \\ should have gained the battle." \\ Napoleon, private \\ correspondence to Admiral \\ Malcolm, 1816, on the \\ unfathomable defeat at Waterloo \\ to Admiral Wellington.
}

Following the rapid expansion of the CIO profession in the past, the present state was ushered in through a strong standing of the CIOs. With a majority of the respondents (14 out of 19) being part of the TMT and involved in shaping the role together with the CEO or by themselves, IT Governance has shifted from being a "ticket to ride" to becoming more and more detrimental to the criticality of the CIO [29]. This detrimental function of IT Governance is highlighted by the decreased risk associated with the role of CIO, with risk being shifted towards the business side through governance models following the logic of supply/demand, with the IT organization shifting over to a reactive rather than a proactive partner to the business. The core logic of the dominating models is hence to delimit fluctuations in demand, resulting in the CIOs shifting over from explorers to exploiters of economies of scale (for a parable, see Boonstra et al, [5]).

The respondents further describe how they have used cognitive strategies to increase their influence. Treatment is more applicable than before due to a generally increased IT understanding, although reduction is still used. However, metaphors have increased in usage due to the professions increased business knowledge and communicative skills. This has in turn decreased the professions residuality, whilst more professions partake in the CIOs jurisdictions, increasing its connectivity.
Up until this point the profession has enjoyed a fruitful journey, one that has increased the professions jurisdictions and made them even more of a generalist profession with less knowledge of their jurisdictions.

"I do not even possess $10 \%$ of their (subordinates) expertise within their areas, I can show the way and say 'this is what we have to do"" - CIO 17, Insurance

This expansion of jurisdictional control has created a divide within the profession, creating two subprofessions, one technologically oriented and one business oriented. A majority of respondents stated that they belonged to the business oriented.

"I do not work with IT. I work with humans, power structures and politics." - CIO 18, Recycling

The profession is hence on the verge of rebellion in the ranks between the two sub-profession. A respondent even went so far as to describe the technological sub-profession as "fake" and as " $a$ dying breed". The profession is no longer just ambiguous to outsiders, even its practitioners cannot agree upon what they are. As the CIOs fight amongst themselves, another profession is emerging in the form of the Chief Digital Officer (CDO), whose primary ambition is to be in control of digital transformation and questions that are more related to business, areas currently controlled by the CIO. The CDOs secret weapon is its new and untainted resume, which has caused it to interfere with the CIO.

The CIO profession's connectivity has since the success of the 1990's and noughties been reduced, with other roles in the organization embracing digitalization $[2 ; 8 ; 13 ; 20 ; 23 ; 24 ; 26 ; 36 ; 41 ; 44 ; 47 ; 52 ; 55]$.

\subsection{Future: Dunkirk}

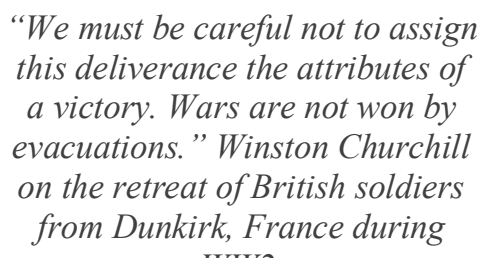

$W W 2$.

Following the success and subsequent demise of the profession of CIOs as portrayed in the past and present above, the future of the $\mathrm{CIO}$ as found in this study is expected to follow one of two scenarios.

There is no agreed upon view of the profession's future amongst the respondents, apart from that the profession is moving closer to business related activities rather than support related technological 
activities. From this perspective, the profession has shifted away from the core of the original profession, that which allowed them significant leeway in the past due to being unconflicted by neighboring professions strive for increased jurisdictional control.

Technical competence is, however, still expected to be required as a tool for understanding how IT can be used to create competitive advantage. With the increasing pervasiveness of IT through digitalization, that which is seen as "core IT" will however continue to shift.

In relation to new roles, several respondents argue that the CDO profession is ephemeral and will disappear in the near future. Another perspective is that the CDO is in charge of organizations digitalization whilst being a subordinary to the $\mathrm{CIO}$ who remains in control of the jurisdiction. Other respondents paint a different picture. Whilst the CIO's resume is haunted by distrust and mismatching expectations by its surroundings, the CDO acts as a "revitalizer" meant to drive questions regarding digitalization that will conquer the CIOs jurisdictions. The CIO profession merely paves the way for the CDO regarding digitalization. Another perspective is that the CIO is a $\mathrm{CDO}$, but with more technical jurisdictions.

"By removing the infrastructure and technology from the $C I O$, you create the $C D O$, which is closer to the business. But in the near future the technical parts of IT are something you must still deal with." - CIO 3, Education
One re-occurring theme in the interviews is a feeling of irrelevance regarding the naming of the profession. A clear majority of the respondents' state that it is "same same but different". On the other hand, a minority of the respondents (2/19) foresee the profession's demise, as IT's role in competitive advantage becomes a pervasive and a more distributed responsibility.

"The CIO has existed for a while now and I believe the CDO will disappear quicker than the CIO, but I also believe the $\mathrm{CIO}$ will disappear." - $\mathrm{CIO} 7$, Agency

To summarize, the future holds one of two scenarios for the CIO profession according to the analysis and findings. Either (Scenario 1) we see a shift towards the $\mathrm{CIO}$ becoming obsolete in terms of being a business partner (due to jurisdictional control being shifted to the new role of the CDO). This will result in the CIO becoming pushed back towards "merely" responsible for the underlying infrastructure, much along the lines of the previous role of CTO. An alternative (Scenario 2) is the revamping of the CIO profession into accepting risk, shifting governance towards breaking with the underlying logic of Supply/demand and emerging as the chief executive of digitalization. Provided the current development of the CIO profession as found in this study, Scenario 1 is found to be the most likely out of these two.

Table 3 summarizes the three phases of the CIO profession from Abbott's system of profession [1].

Table 3. Summary of findings in relation to Abbott's system of professions.

\begin{tabular}{|c|c|c|c|}
\hline Mechanism & Past & Present & Future \\
\hline Connectivity & $\begin{array}{l}\text { High connectivity due to low level } \\
\text { of external involvement and high } \\
\text { level of autonomy. }\end{array}$ & $\begin{array}{l}\text { Decreasing level of connectivity } \\
\text { due to increased external } \\
\text { standardization, regulation and } \\
\text { involvement from other actors. }\end{array}$ & $\begin{array}{l}\text { Continued decrease level of } \\
\text { connectivity due to more and } \\
\text { more decisions falling outside of } \\
\text { the professions jurisdictional } \\
\text { control. }\end{array}$ \\
\hline Dominance & $\begin{array}{l}\text { Inclusion in TMT and shifts in } \\
\text { reporting structures increases the } \\
\text { dominance of the profession. }\end{array}$ & $\begin{array}{l}\text { Shift to cultural rather than } \\
\text { structural dominance. Decreasing } \\
\text { involvement in TMT through new } \\
\text { roles taking responsibility over } \\
\text { digital transformation. }\end{array}$ & $\begin{array}{l}\text { Further increase of cultural rather } \\
\text { than structural dominance, yet } \\
\text { new ideas such as digital } \\
\text { transformation are increasingly } \\
\text { adopted and adapted into new } \\
\text { perspectives and ideas by } \\
\text { neighboring professions [HR, } \\
\text { Finance etc]. }\end{array}$ \\
\hline Residuality & High level of residuality & $\begin{array}{l}\text { Decreased level of residuality, yet } \\
\text { a burgeoning residuality in regards } \\
\text { to how the profession is involved } \\
\text { in digital transformation. }\end{array}$ & $\begin{array}{l}\text { Decreased level of residuality as } \\
\text { the CIO is circumvented through } \\
\text { other professions taking control } \\
\text { over the digital agenda and the } \\
\text { CIO is pushed into specialization } \\
\text { and delimitation to technology and } \\
\text { procurement. }\end{array}$ \\
\hline $\begin{array}{l}\text { Systemization } \\
\text { of }\end{array}$ & $\begin{array}{l}\text { Low degree of systemized } \\
\text { professional knowledge. }\end{array}$ & $\begin{array}{l}\text { Continued low degree of } \\
\text { systemization. }\end{array}$ & $\begin{array}{l}\text { The influx of new professions } \\
\text { grappling for control over }\end{array}$ \\
\hline
\end{tabular}




\begin{tabular}{|c|c|c|c|}
\hline $\begin{array}{l}\text { professional } \\
\text { knowledge }\end{array}$ & & & $\begin{array}{l}\text { digitalization will shift the } \\
\text { systematization of traditional CIO } \\
\text { knowledge to other professions. }\end{array}$ \\
\hline Reduction & $\begin{array}{l}\text { Business knowledge and } \\
\text { communicative skills shift from } \\
\text { low to medium among CIOs, } \\
\text { coupled with constant low } \\
\text { understanding of IT from the } \\
\text { external system[s]. Reduction } \\
\text { used frequently. }\end{array}$ & $\begin{array}{l}\text { External IT knowledge has } \\
\text { increased, yet with a continued } \\
\text { strong internal position the CIOs } \\
\text { still use reduction to assert power. }\end{array}$ & $\begin{array}{l}\text { Overall increased IT know-how } \\
\text { will reduce the use of reduction by } \\
\text { CIOs. }\end{array}$ \\
\hline Metaphor & $\begin{array}{l}\text { Metaphor is seldom used to } \\
\text { increase jurisdictional control. }\end{array}$ & $\begin{array}{l}\text { Commonly used. Increased focus } \\
\text { on digitalization coupled with } \\
\text { increased awareness and } \\
\text { understanding from business } \\
\text { opens up. }\end{array}$ & Continued increase in metaphor. \\
\hline Treatment & $\begin{array}{l}\text { Outside perceptions of IT change } \\
\text { the use of treatment. More and } \\
\text { more influx of IT solutions to } \\
\text { traditional business problems. }\end{array}$ & $\begin{array}{l}\text { Increased external IT } \\
\text { understanding increases the ability } \\
\text { to instill treatment. }\end{array}$ & $\begin{array}{l}\text { Continued increase in treatment } \\
\text { through agile, bimodal etc. }\end{array}$ \\
\hline $\begin{array}{l}\text { Positive } \\
\text { formalism }\end{array}$ & $\begin{array}{l}\text { Shift from a high to low level of } \\
\text { positive formalism in line with } \\
\text { shift from technology } \\
\text { championship. }\end{array}$ & $\begin{array}{l}\text { Continued reduction of positive } \\
\text { formalism through specialization. }\end{array}$ & Increased specialization. \\
\hline $\begin{array}{l}\text { Lack of } \\
\text { content }\end{array}$ & $\begin{array}{l}\text { Shift from specialist to [more] } \\
\text { generalist approach as CIO } \\
\text { appropriated new avenues of } \\
\text { control. }\end{array}$ & $\begin{array}{l}\text { Increased lack of content due to } \\
\text { decreased specialization. }\end{array}$ & Increased specialization. \\
\hline Amalgamation & Uncommonly used. & $\begin{array}{l}\text { CIOs are increasingly trying to } \\
\text { appropriate the digital agenda } \\
\text { through amalgamation. }\end{array}$ & $\begin{array}{l}\text { Decreased use of amalgamation } \\
\text { due to new roles emerging [CDO } \\
\text { etc]. }\end{array}$ \\
\hline Division & $\begin{array}{l}\text { Commonly used as a means for } \\
\text { increasing level of specificity } \\
\text { within the IT organization. New } \\
\text { roles emerge. }\end{array}$ & $\begin{array}{l}\text { Commonly used tactic to increase } \\
\text { the status of the role of the CIO by } \\
\text { removing technical aspects of the } \\
\text { role. }\end{array}$ & $\begin{array}{l}\text { Increased use of division in cases } \\
\text { where amalgamation was tried but } \\
\text { failed. }\end{array}$ \\
\hline
\end{tabular}

\section{Discussion}

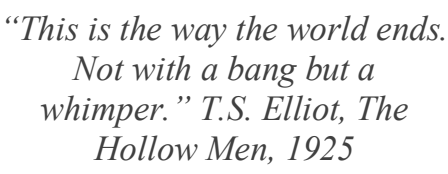

The analysis of the past, present and future of the profession of the CIO paints a gloomy picture in terms of the evolution of the CIOs jurisdictional control. In line with the above quote of T.S. Elliot, the story is one of slow and continuous decline rather than singular implosion. Following an era (19802000) of expanded jurisdictional control through formalization of IT Governance [56] the strive for decreasing risk associated with the $\mathrm{CIO}$ and decrease CIO turnover soon turned into a double-edged sword. Albeit protecting the CIO from risk exposure, the manner through which this was done involved several instances of specialization, division and decrease in scope of jurisdictional control that by now are proving counter-productive for the profession's longterm viability.
In terms of the system properties and connectivity, we see an increasing marginalization of the CIO role and responsibilities, with new professions and institutions coming into play and with the CIO profession decreasing jurisdictional control. The increased dependence on IT within society at large has also ushered in new regulation which circumvents previous connectivity. Regarding dominance, structural control has been lost due to inappropriateness of chosen governance configuration for the technology's development and criticality for business innovation. The dominant ideas are now shifting towards application rather than technology [58], whereby other professions gain momentum and increased jurisdictional control. With increased formalization and subsequent division of labor outside of the jurisdictional control of the CIO, the professional scope is increasingly well defined and limited, whereby the residuality continues to decrease. There is also a continuous inability to systematize knowledge, which has resulted in less latency in the loss of jurisdictional control, i.e. the loss of professional status is expected to be rapid [1]. 
In terms of the cognitive strategies, with IT knowhow disseminated throughout the organization(s), the avenue of reduction for diagnosis is increasingly unattainable for CIOs. A similar pattern emerges within the strategy of metaphor, where the role of "IT knowledge" has changed and been appropriated by neighboring professions [53]. Without a strong profession to claim ownership, metaphor becomes invaluable for increased jurisdictional control. Without a strong profession to claim ownership, treatment similarly becomes invaluable for increased jurisdictional control.

In regards of abstraction, both positive formalism and content are influenced negatively over time. With a decrease in professional jurisdiction, the increased specialization fails to create a strong center of gravity in terms of abstract knowledge for the profession.

When it comes to the maintaining of jurisdictional control, division replaces amalgamation as the core approach, with a disintegration of the profession of $\mathrm{CIO}$ as a consequence. Instead of amassing new areas of jurisdictional control through amalgamation, the profession slices out areas such as security (Chief Security Officer) and digitalization (CDO) through division.

When combined, this analysis points to an initiated and seemingly unavoidable retreat of the CIO profession from the frontiers of digitalization. A systematic decimation of jurisdictional control has been going on since the advent of formalized IT Governance. In this respect, we can see the governance frameworks such as COBIT, ISO38500 and ITIL as mechanisms of deprofessionalization [18]. With an increasing dependency on said frameworks in the late 1990's and early noughties, the CIO profession made an active, collective choice to decrease its own jurisdictional control. This was, as argued by Magnusson and Bygstad [29], done instrumentally in order to attain a "ticket to ride" in the higher echelons of management and hence increase the internal status of the CIO and ITdepartment. In other words, there is a tradeoff associated with this particular type of attainment of increased social standing and the long-term viability of the profession.

Returning to the battle references used as illustrations of the three phases of the CIO profession's evolution, the expected Dunkirk of the future is intricately dependent upon both the Bastille and Waterloo. What made victory possible in the past is now a core pre-requisite of the defeat of the present and the retreat of the future. This is, to return to the title of this paper, how the West with all its grand opportunities was lost.

\subsection{Implications for research}

We see three main implications for research coming out from this study. First, research should increase its utilization of theories stemming from the sociology of work and occupations in order to better be able to see the longitudinal effects of shifts in professional roles and functions. The CIO has been a significant actor in the computerization and digitalization of business and society and will most likely have an effect on future developments. In order to increase our understanding of this, frameworks such as that of Abbott [1] may be relevant for future studies.

Second and as a continuation of the first, the study of CIOs need to be seen in a context where neighboring professions strive for jurisdictional control has a significant impact on the role of the CIO. As we will now expect to see an increasing amount of studies directed towards better understanding the role of the $\mathrm{CDO}$, research would do wise in not studying this out of context.

Third, the potentially detrimental role of governance frameworks as portrayed in this study offers an alternative perspective to the how digitalization is enacted in organizations. As found in Cram et al [9], there is a lack of studies focused on control enactment, and to truly understand the role of governance we need to study its implications in other forms than the dominant, short-term financial perspective (for an example, see [60] and [61]).

\subsection{Implications for practice}

There are two main implications for practice. First, individuals either currently in the role of CIO or aspiring for entering the role may see the findings of this study as a blue-print of what to expect in terms of future developments and risks associated with the choice of profession. As noted, the most likely development will infer a continued marginalization of the CIO in terms of corporate power. At the same time, the findings provide an overview of potential risks that may be diverted, provided the individual in question displays caution. The findings associated with the innate relationship between risk and reward could be used as a battle cry for future CIOs becoming more risk prone, accepting that the role of innovation partner is one that is incompatible with structural risk aversion.

Second, organizations striving for continued digitalization should take heed to the manner in which IT Governance may act detrimental to digitalization success. In designing governance and the jurisdictional control of the CIO, organizations need to be aware of the implications of shifting power away from the profession which currently has 
the utmost responsibility for the underlying infrastructure and data. Increasing [or cementing] the gap between supply and demand will invariably result in increased coordination costs and lead times, in a time when the bulk of business initiatives are highly dependent upon data. Hence, seeing the highly operative role of the CDO [54] as a magic bullet for digitalization may turn out to be a blunt.

\subsection{Future research}

We see two projects coming out from the research presented in this paper. First, we call for research that studies the $\mathrm{CIO}$ neighboring professions (CFO, CTO, CDO, CEO et cetera) from the perspective of jurisdictional control. The object of jurisdictional control should in this manner be that of digitalization, whereby we would be able to better understand how digitalization should be organized and governed for optimal effect given the context of existing and emerging professions.

Second, the dark side of governance frameworks needs to be addressed in more detail. The findings of this study give an indication of governance having an impact on professions, but at the same time we have but scratched the surface. Hence, we see the need for an additional study of the relationship between formal controls and professions, where the controls themselves become an actor in the development of professions. This research would do wise in utilizing inspiration from the current developments within the management of digital innovation, as outlined in Nambisan et al [33].

\subsection{Conclusions}

This study has focused on the evolution of the profession of $\mathrm{CIO}$ in the past, present and future. Through utilizing Abbott's [1] theory of the system of professions in combination with the findings from a literature review and an interview study, the study finds that the CIO profession has emerged from an initial increase in jurisdictional control towards a significant decrease that threatens the very profession itself. The decrease in jurisdictional control is associated with the imposition of IT Governance frameworks designed to shift the risks of the profession to neighboring professions and other areas of the business. The findings are intended to aid researchers and practitioners alike in a quest for designing both governance and CIO responsibilities in the future, as well as to aid us in better understanding the future implications of choices in governance.

\section{References}

[1] Abbott, Andrew. The system of professions: An essay on the division of expert labor. University of Chicago Press, 2014.

[2] Armstrong, Curtis P., and Vallabh Sambamurthy. "Information technology assimilation in firms: The influence of senior leadership and IT infrastructures." Information systems research 10, no. 4 [1999]: 304-327.

[3] Banker, Rajiv D., Nan Hu, Paul A. Pavlou, and Jerry Luftman. "CIO reporting structure, strategic positioning, and firm performance." MIS quarterly 35, no. 2 [2011]: 487-504.

[4] Benjamin, Robert I., Charles Dickinson Jr, and John F. Rockart. "Changing role of the corporate information systems officer." MIS quarterly [1985]: 177-188.

[5] Boonstra, Albert, U. Yeliz Eseryel, and Marjolein AG van Offenbeek. "Stakeholders' enactment of competing logics in IT governance: polarization, compromise or synthesis?." European Journal of Information Systems [2017]: 1-19.

[6] Clayton, Rich. "CFOs take notice big data may be your new best friend." Financial Executive 29, no. 10 [2013]: 22-26.

[7] Chun, Mark, and John Mooney. "CIO roles and responsibilities: Twenty-five years of evolution and change." Information \& management 46, no. 6 [2009]: 323334.

[8] Cote, Joe. "Talking to your CIO to get the data you need.[Workforce Optimization]." Financial Executive 18, no. 5 [2002]: 44-48.

[9] Cram, W. Alec, Kathryn Brohman, and R. Brent Gallupe. "Information systems control: a review and framework for emerging information systems processes." Journal of the Association for Information Systems 17, no. 4 [2016]: 216.

[10] Enns, Harvey G., Sid L. Huff, and Brian R. Golden. "CIO influence behaviors: the impact of technical background." Information \& Management 40, no. 5 [2003]: 467-485.

[11] Enns, Harvey G., Sid L. Huff, and Christopher A. Higgins. "CIO lateral influence behaviors: Gaining peers' commitment to strategic information systems." In Proceedings of the twenty first international conference on Information systems, pp. 457-460. Association for Information Systems, 2000.

[12] Gerth, Anthony B., and Joe Peppard. "The dynamics of CIO derailment: How CIOs come undone and how to avoid it." Business Horizons 59, no. 1 [2016]: 61-70. 
[13] Glaser, John P. "Working with the CIO: how well do you know your CIO?." Healthcare Financial Management 59, no. 7 [2005]: 108-111.

[14] Glaser, John, and Judy Kirby. "Evolution of the healthcare CIO." Healthcare financial management: journal of the Healthcare Financial Management Association 63, no. 11 [2009]: 38-41.

[15] Gottschalk, Petter. "Strategic management of IS/IT functions: the role of the CIO in Norwegian organisations." International Journal of Information Management 19, no. 5 [1999]: 389-399.

[16] Grover, Varun, Seung-Ryul Jeong, William J. Kettinger, and Choong C. Lee. "The chief information officer: A study of managerial roles." Journal of management information systems 10, no. 2 [1993]: 107130.

[17] Gupta, Yash P. "The chief executive officer and the chief information officer: the strategic partnership." Journal of Information Technology 6, no. 3-4 [1991]: 128-139.

[18] Haug, Marie R. "Deprofessionalization: an alternate hypothesis for the future." The Sociological Review 20, no. S1 [1972]: 195-211.

[19] Highbarger, John E. "What's the Proper Role for the CIO?." Management Review 77, no. 11 [1988]: 53.

[20] King, William R. "Including the CIO in top management." Information systems management 25 , no. 2 [2008]: 188-189.

[21] Khallaf, Ashraf, and Munir Majdalawieh. "Investigating the Impact of CIO competencies on IT security performance of the US Federal Government Agencies." Information Systems Management 29, no. 1 [2012]: 55-78.

[22] Kirkley, Jeff. "Why the CFO should talk to the CIO... now: research suggests that in many organizations, communications between the two C-suite officers is suspect. But with so many key controls, risks and procedures at stake, a good rapport is essential." Financial Executive 23, no. 2 [2007]: 20-23.

[23] Krotov, Vlad. "Bridging the CIO-CEO gap: It takes two to tango." Business Horizons 58, no. 3 [2015]: 275283.

[24] LAWLER III, EDWARD E., and David Finegold. "Who's in the Boardroom and Does It Matter:: The Impact of having Non-director Executives Attend Board Meetings." Organizational dynamics 35, no. 1 [2006]: 106115 .

[25] Leidner, Dorothy E., and Jane M. Mackay. "How incoming CIOs transition into their new jobs." MIS Quarterly Executive 6, no. 1 [2007].
[26] Li, Mingfang, and L. Richard Ye. "Information technology and firm performance: Linking with environmental, strategic and managerial contexts." Information \& Management 35, no. 1 [1999]: 43-51.

[27] Marshall, Jeffrey. "Finance and IT: A Need to Work Together; While Their Roles Are Very Different, CIOs and CFOs Say That More than Ever, They Need to Cooperate and Plan Together to Cost-effectively Deliver Systems and Applications That Companies Need to Thrive.[cost Management][chief Information Officer][chief Financial Officer]." Financial Executive 20, no. 6 [2004]: 36-42.

[28] Magnusson, Johan. "Unpackaging IT governance." Gothenburg: BAS Publishing [2010].

[29] Magnusson, Johan, and Bendik Bygstad. "Why I act differently: studying patterns of legitimation among CIOs through motive talk." Information Technology \& People 26, no. 3 [2013]: 265-282.

[30] McFarlane, F. Warren. Information technology changes the way you compete. Harvard Business Review, Reprint Service, 1984.

[31] Millar, V. E. "The emergence of the chief information officer." Management Review 72, no. 2 [1983]: 29.

[32] Murray, Dave. "Optimizing the business benefits from technology acquisitions: making intelligent technology purchases requires a vision, a long-term strategy and the knowledge that desired objectives are attainable. Smart companies--moving toward single data repositories across their enterprises--are doing things smarter, faster and better." Financial Executive 22, no. 5 [2006]: 36-42.

[33] Nambisan, Satish, Kalle Lyytinen, Ann Majchrzak, and Michael Song. "Digital innovation management: Reinventing innovation management research in a digital world." Mis Quarterly 41, no. 1 [2017].

[34] Naukam, Drew. "Finance must adapt to cloud-based subscription models." Financial Executive 30, no. 2 [2014]: 100-104.

[35] O'Donnell, David, Nick Bontis, Philip O'Regan, Tom Kennedy, Peter Cleary, and Ailish Hannigan. "CFOs in e-business: e-architects or foot-soldiers?." Knowledge and Process Management 11, no. 2 [2004]: 105-116.

[36] Palmer, Ian. "CFOs and IT: Finding the Right Balance." Financial Executive 19, no. 9 [2003]: 26-29.

[37] Palmlund, David. "In search of the ideal CIO." Financial Executive 13, no. 3 [1997]: 37-40.

[38] Plewa, Jeffrey M., and H. Thaine Lyman. "Keeping the customer satisfied: the new CIO mandate." Information systems management 9, no. 1 [1992]: 54-61. 
[39] Peppard, Joe. "Unlocking the performance of the chief information officer [CIO]." California Management Review 52, no. 4 [2010]: 73-99.

[40] Peppard, Joe, Chris Edwards, and Rob Lambert. "Clarifying the Ambiguous Role of the CIO." MIS Quarterly Executive 10, no. 1 [2011].

[41] Polansky, Mark, Tarun Inuganti, and Simon Wiggins. "The 21st century CIO." Business Strategy Review 15, no. 2 [2004]: 29-33.

[42] Porter, Michael E., and Victor E. Millar. "How information gives you competitive advantage." [1985].

[43] Preston, David S., Dorothy E. Leidner, and Daniel Chen. "CIO leadership profiles: Implications of matching CIO authority and leadership capability on IT impact." MIS Quarterly Executive 7, no. 2 [2008].

[44] Preston, David S., and Elena Karahanna. "Antecedents of IS strategic alignment: a nomological network." Information systems research 20, no. 2 [2009]: 159-179.

[45] Ravichandran, T., and Yu Liu. "Environmental factors, managerial processes, and information technology investment strategies." Decision Sciences 42, no. 3 [2011]: 537-574.

[46] Raelin, Joseph A. "An anatomy of autonomy: Managing professionals." The Academy of Management Executive 3, no. 3 [1989]: 216-228.

[47] Reinhard, James. "IT governance integration: auditors can use their assessment and advisory skills to help management strengthen alignment between the IT function and enterprise strategy." Internal Auditor 69, no. 4 [2012]: 51-55.

[48] Rockart, John F., Leslie Ball, and Christine V. Bullen. "Future role of the information systems executive." MIS quarterly [1982]: 1-14.

[49] Romanczuk, Jeffrey B., and J. Michael Pemberton. "The chief information officer: Rise and fall?." Information Management 31, no. 2 [1997]: 14.

[50] Samuel, Sajay, Mark W. Dirsmith, and Barbara McElroy. "Monetized medicine: from the physical to the fiscal." Accounting, Organizations and Society 30, no. 3 [2005]: 249-278.

[51] Schobel, Kurt, and James S. Denford. "The chief information officer and chief financial officer dyad in the public sector: How an effective relationship impacts individual effectiveness and strategic alignment." Journal of Information Systems 27, no. 1 [2012]: 261-281.

[52] Stewart, Aimee. "Online Procurement 101. [Brief Article]." Financial Executive 16, no. 4 [2000]: 12.
[53] Tiwana, Amrit, and Stephen K. Kim. "Discriminating IT governance." Information Systems Research 26, no. 4 [2015]: 656-674.

[54] Tumbas, Sanja, Nicholas Berente, and Jan vom Brocke. "Three Types of Chief Digital Officers and the Reasons Organizations Adopt the Role." MIS Quarterly Executive 16, no. 2 [2017].

[55] Van Decker, John E., and William M. Sinnett. "The CFO's top technology imperatives." Financial Executive 29 , no. 5 [2013]: 25-29.

[56] Weill, Peter, and Jeanne W. Ross. IT governance: How top performers manage IT decision rights for superior results. Harvard Business Press, 2004.

[57] Yayla, Ali Alper, and Qing Hu. "The effect of board of directors' IT awareness on CIO compensation and firm performance." Decision Sciences 45, no. 3 [2014]: 401436.

[58] Yoo, Youngjin, Ola Henfridsson, and Kalle Lyytinen. "Research commentary - the new organizing logic of digital innovation: an agenda for information systems research." Information systems research 21, no. 4 [2010]: 724-735.

[59] Zorko, Mark. "E-commerce: How CFOs can seize the initiative." Financial Executive 17, no. 3 [2001]: 36-36.

[60] Rolland, K. H., Mathiassen, L., \& Rai, A. (2018). Managing digital platforms in user organizations: The interactions between digital options and digital debt. Information Systems Research, 29(2):419-443.

[61] Hinings, B., Gegenhuber, T., \& Greenwood, R. (2018). Digital innovation and transformation: An institutional perspective. Information and Organization, 28(1), 52-61. 